Zabytkoznawstwo i Konserwatorstwo XXXVIII, Toruń 2010

Justyna Olszewska-Świetlik

Uniwersytet Mikołaja Kopernika w Toruniu

\title{
Zagadnienia warsztatu malarskiego epitafium Hansa Gronau z Bazyliki Mariackiej w Gdańsku
}

\footnotetext{
dańsk w XVII stuleciu był znaczącym ośrodkiem kultury i sztuki. JW mieście działali wybitni artyści, których twórczość oddziaływała na obszar całej Polski, zwłaszcza jej północnej części.

Do czołowych artystów pierwszej połowy XVII wieku zalicza się między innymi Antona Möllera (1563/1565 Królewiec-1611 Gdańsk), który wykonywał wiele dzieł zdobiących zarówno budynki użyteczności publicznej, jak i kościołyl. Wybitna osobowość twórcy, który był właścicielem znaczącego warsztatu malarskiego i autorem licznych zamówień, wywarła duży wpływ na sztukę tego czasu. Prace Möllera były inspiracją dla innych warsztatów działających w tym okresie na Pomorzu. W Bazylice Mariackiej w Gdańsku

1 Por. T. Grzybkowska, Złoty wiek malarstwa gdańskiego na tle kultury artystycznej miasta 1520-1620, Warszawa 1990, s. 138-157; eadem, Niderlandyzm w sztuce gdańskiej, [w:] Niderlandyzm w sztuce polskiej. Materiaty z Sesji Stowarzyszenia Historyków Sztuki, Torun, grudzień 1992, Warszawa 1995, s. 106-110; J. Friedrich, J. Dziubkowa, nota biograficzna oraz T. Grzybkowska nr kat. IV.3-4, K. Górecka-Petrajtis nr kat. IV.5 i V.66, J. Dziubkowa nr kat. V.60.1-60.3, G. Zinówko nr kat. V.63, [w:] Aurea Porta Rzeczypospolitej. Sztuka Gdańska od połowy X do końca XVIII wieku. Katalog, Gdańsk 1997, s. 454-455, 97-98, 186-187, 179-183, 184-185. Tryptyk Model świata i społeczeństwa gdańskiego, nr kat. 60.1-60.3, przypisywany był w literaturze A. Möllerowi, w najnowszej publikacji: Herman Han. Mistrz światła i nokturnu. Narodziny baroku w malarstwie dawnej Rzeczypospolitej, pod red. M. Osowskiego, Pelplin 2008, nr kat. I.65A.B.C, s. 194-197, przypisany został Hermanowi Hanowi. Na tym tle wydaje się, że przeprowadzenie badań budowy technicznej obrazów obu mistrzów pomogłoby w rozwiązaniu atrybucji ich dzieł.
} 
oprócz dzieł namalowanych przez mistrza zostały ufundowane obrazy, w których zauważalne są wpływy jego twórczości². W nawie północnej bazyliki, na przyporze pomiędzy kaplicami św. Anny i Zbawiciela, eksponowane jest epitafium Hansa Gronau, które wiąże się z kręgiem oddziaływania sztuki Antona Möllera ${ }^{3}$. Celem niniejszego opracowania jest określenie budowy technicznej obrazu oraz charakterystyka warsztatu malarskiego ${ }^{4}$.

2 T. Grzybkowska, Malarstwo, [w:] Aurea Porta Rzeczypospolitej. Sztuka Gdańska od połowy XV do końca XVII wieku. Eseje, Gdańsk 1997, s. 39-41.

3 R. Sulewska, Dtutem wycięte, Warszawa 2004, nr kat. 51, s. 219-220 (tam bibliografia).

4 Epitafium było przedmiotem badań większego projektu finansowanego w ramach grantu MNSW nr N 10503731/3704 pt. Technologia i technika malarska wybranych nowożytnych epitafiów Bazyliki Mariackiej w Gdańsku. Do identyfikacji materiałów zastosowano następujące metody badawcze: analizę i fotografię w IR i UV, lica obrazów wykonał mgr A. Cupa, interpretacji dokonała autorka artykułu w Zakładzie Technologii i Technik Malarskich IZK, UMK w Toruniu. Do badań w podczerwieni zastosowano cyfrowy system do reflektografii w zakresie bliskiej podczerwieni z filtrem $780 \mathrm{~nm}, \mathrm{w}$ UV lampe typu Emita z filtrem Wooda $365 \mathrm{~nm}$. Rentgenogramy i fotografia w IR: mgr R. Stasiuk i mgr P. Zambrzycki z Agencji Artystycznej Sztuk Pięknych w Warszawie. Wszystkie próbki pobrała autorka niniejszej pracy. Próbki zatopiono w żywicy „Duracryl Plus” prod. Spofa, Dental - Czechy, wyszlifowano przy użyciu papierów ściernych o granulacji od 300 do 2000. Obserwację wykonano z zastosowaniem mikroskopu Optiphot 2, powiększenie 40 i 100 razy, w Zakładzie Technologii i Technik Malarskich IZK, UMK w Toruniu. Fotografię przekrojów fluorescencji w ultrafiolecie wykonała dr Zuzanna Rozłucka w Zakładzie Konserwacji Malarstwa i Rzeźby Polichromowanej IZK, UMK w Toruniu. Używano mikroskopu fluorescencyjnego Nikon Eclipse E 600, powiększenie 100 i 200 razy, zintegrowanego z lampa rtęciową Nikon Super HB 1010AF i standardowym blokiem filtrów UV 2A: EX 330-380 nm, DM 400 nm, BA 420 nm. Na temat zastosowanej metody i aparatury patrz: Z. Rozłucka, M. Roznerska, J. Arszyńska, Mikroskopia fluorescencyjna. Zastosowanie $w$ badaniu budowy i procesów konserwacji malarstwa sztalugowego, Torun 2000. Badania mikrochemiczne wykonano na przekrojach poprzecznych i wypreparowanych warstwach. Przeprowadzono analizy w roztworze: reakcje mikrokrystaloskopowe, kroplowe, analizy suche, prażenie, barwienie płomienia perły boraksowej. Zastosowano metody instrumentalne do badań pigmentów i barwników: rentgenowska analiza fluorescencyjna XRF z użyciem energodyspersyjnego spektrometru rentgenowskiego z układem helowym Mini Pal PW 4025, autor: mgr A. Cupa, Zakład Technologii i Technik Malarskich IZK, UMK w Toruniu; energodyspersyjna analiza rentgenowska z zastosowaniem mikrosondy elektronowej (SEM-EDS), skaningowy mikroskop elektronowy JEOL JSM-6380LA, Pracownia Mikroskopii Elektronowej i Mikroanalizy, Uniwersytet Warszawski, autor: mgr M. Wróbel; neutronowa analiza aktywacyjna, autor: 
Epitafium ze sceną Sądu Ostatecznego zostało ufundowane w roku 1612 i należy do typu obrazowego ozdobionego rzeźbioną ramą architektoniczną z ornamentem rollwerkowo-okuciowym. Po bokach na konsolach rzeźby przedstawiające personifikacje Męstwa Chrześcijańskiego i Pobożności. W zwieńczeniu kartusz herbowy i rzeźba puttów. Na dole tablica inskrypcyjna $^{5}$ (il. 1). Obraz o wymiarach $159 \mathrm{~cm} \times 119 \mathrm{~cm}$ został namalowany na podobraziu drewnianym. Deski wycięto z pnia w kierunku promieniowym i sklejono na styk. Na podobrazia po uprzednim przeklejeniu klejem glutynowym nałożono dwukolorową zaprawę o łącznej grubości około $100 \mu \mathrm{m}$. Zaprawa w kolorze białym miała za zadanie wygładzenie nierówności podłoża. Nałożona została cienko, a jej grubość nie przekracza $40 \mu \mathrm{m}$. Spoiwem zaprawy jest klej glutynowy, wypełniaczem kreda $\mathrm{CaCO}_{3}$ z niewielkim dodatkiem bieli ołowiowej $2 \mathrm{PbCO}_{3} \cdot \mathrm{Pb}(\mathrm{OH})_{2}$. Druga zaprawa o odcieniu brązu i grubości około $60 \mu \mathrm{m}$ nadawała ciepły odcień podłożu oraz odgrywała rolę odpowiedniego podkładu stosowanego do malowania tłustego spoiwa. Do jej wykonania użyto spoiwa emulsyjnego o składzie: klej białkowy, olej lniany oraz mieszaniny wypełniaczy: kreda $\mathrm{CaCO}_{3}$, minia $\mathrm{Pb}_{3} \mathrm{O}_{4}$, czerń roślinna. Schyłek wieku XVI oraz początek XVII był okresem wprowadzania do malarstwa zapraw barwnych. Na początku tonowano białą zaprawe poprzez zastosowanie imprimatury. Później zaczęto używać kolorowych zapraw. W traktacie de Mayerne'a znajdujemy przepisy dotyczące gruntowania zarówno na desce, jak i płótnie. Do podobrazi drewnianych de Mayerne zaleca cienką warstwę wyrównującą podłoże składającą się z kredy i kleju glutynowego. Następnie

mgr inż. E. Pańczyk, Instytut Chemii i Techniki Jądrowej w Warszawie; wysokosprawna chromatografia cieczowa HPLC, główne składniki zidentyfikowano przy użyciu sprzężonej z nią spektrometrii UV-VIS, autor: mgr W. Nowik, Laboratoire de Recherche des Monuments Historiques, Francja; chromatografia gazowa GC (większość próbek badano po rozkładzie $\mathrm{KOH}$, wybrane po $\mathrm{HCl}$ ), autor: mgr G. Jaworski, Zakład Technologii i Technik Malarskich IZK, UMK w Toruniu. Wyniki badań zawarte w: J. Olszewska-Świetlik, Technologia i technika malarska wybranych nowożytnych epitafiów z Bazyliki Mariackiej w Gdańsku, Toruń 2009, s. 87-102.

5 Ks. St. Bogdanowicz, Dzieła sztuki sakralnej Bazyliki Mariackiej w Gdańsku, Gdańsk 1990, s. 363-364; R. Sulewska, op. cit., s. 219-220. 
należało nanieść cienką warstwę bieli ołowiowej i umbry . Stosowanie dwukolorowych zapraw stanowiło przejście do zapraw barwionych w całej masie. W tych przypadkach widać łączenie dawnej tradycji z nowymi tendencjami. Po odpowiednim przygotowaniu zaprawy wykonano zapewne rysunek kompozycji. Nie zidentyfikowano go podczas badań w podczerwieni. Analizując kompozycję Sądu Ostatecznego, stwierdzono, że była ona wzorowana na sztychu Jana Sadlera ${ }^{7}$. Wykazuje ona również wiele zbieżności z zaginionym obrazem Antona Möllera z Dworu Artusa (1602-1603), z epitafium ławnika staromiejskiego Jacoba Schmidta z 1595 roku z kościoła św. Katarzyny w Gdańsku, obecnie w zbiorach Muzeum Narodowego w Gdańsku, oraz z obrazem z kościoła św. Jakuba w Toruniu ${ }^{8}$.

Opracowanie malarskie wykonano w technice wielowarstwowej. Spoiwem była tłusta emulsja typu woda w oleju (w/o) o składzie: olej lniany, kazeina. Laserunki wykonano spoiwem olejno-żywicznym. Warstwy malarskie nakładano zazwyczaj 2-3-krotnie, a ich grubość wahała się w granicach od 20 do $100 \mu \mathrm{m}$. Modelunek malarski rozpoczynano od podmalowania. Wykonano je w kolorze lokalnym, wybrane elementy kompozycji podmalowano szarością. Paleta malarska składała się z następujących pigmentów i barwników organicznych: biel ołowiowa $2 \mathrm{PbCO}_{3} \cdot \mathrm{Pb}(\mathrm{OH})_{2}$, żółcień cynowo-ołowiowa, żółcień żelazowa, smalta, azuryt naturalny $2 \mathrm{CuCO}_{3} \cdot \mathrm{Cu}(\mathrm{OH})_{2}$, cynober $\mathrm{HgS}$, minia $\mathrm{Pb}_{3} \mathrm{O}_{4}$, karmin, kraplak, czerń roślinna. Mimo ograniczonej palety faktycznej uzyskano rozbudowaną paletę optyczną. Obraz jest utrzymany w tonacji ciepłych brązów.

6 T. Turque de Mayerne, [w:] E. Berger, Quellen für Maltechnik während der Renaissance und deren Folgezeit (XVI.-XVIII. Jahrhundert) in Italien, Spanien, den Niederlanden, Deutschland, Frankreich und England nebst dem de Mayerne Manuskrypt, München 1901, s. 276-278; M. Roznerska, Techniki malarskie „Małych Mistrzów Holenderskich” XVII w., Toruń 1991, s. 163.

7 W. Drost, Danziger Malerei von Mittelalter bis zum Ende des Barok, Berlin-Leipzig 1938, s. 127, za karty inwentarzowe, Wojewódzki Urząd Konserwatorski w Gdańsku, autor: K. Cieślak, mps.

8 A. Mosingiewicz, Antoni Möller (ok. 1563-1611) malarz, [w:] Artyści w dawnym Toruniu, pod red. J. Poklewskiego, Warszawa-Poznań-Torun 1985, s. 44-52; T. Grzybkowska, Złoty wiek malarstwa, s. 142; K. Cieślak, Epitafia obrazowe w Gdańsku (XV-XVII w.), Wrocław-Warszawa-Kraków 1993, s. 35-39; eadem, nr kat. IV.34, [w:] Aurea Porta Rzeczypospolitej. Katalog, s. 115. 
Należy zwrócić uwagę na ograniczenie zastosowania pigmentów chłodnych. Pigmenty błękitne powszechnie używane w epoce średniowiecza, takie jak ultramaryna naturalna czy azuryt naturalny, zostały zastapione nietrwałą kolorystycznie smaltą, którą modelowano chmury. W celu uzyskania różowofioletowego odcienia obłoków do smalty dodawano czerwieni organicznej - karminu. Azuryt naturalny zastosowano w ograniczonym zakresie, jedynie do modelunku szat świętych (il. 2). W cieniach błękity podmalowano czernią. Modelunek malarski opracowano azurytem naturalnym z niewielkim dodatkiem karminu w cieniach oraz bieli ołowiowej w światłach. Nie zidentyfikowano zastosowania pigmentów zielonych.

Karnacje namalowano z zastosowaniem niewielkiej ilości pigmentów, uzyskano natomiast rozbudowaną skalę kolorystyczną - od ciepłych brązów do chłodnych, prawie białych świateł. Cienie nakładano cienko półkryjąco. Półtony i światła modelowano po „formie” z widocznym duktem pędzla odwzorowanym w warstwie malarskiej. $\mathrm{Na}$ uwage zasługuje wierne, portretowe oddanie postaci fundatorów. Dbano o ukazanie indywidualnych rysów twarzy. Nie idealizowano, lecz zaznaczano szczegóły niemłodych już osób, pokazywano zmarszczki oddające wiek (il. 3, 4).

Ekspresyjnie namalowano postacie w partii piekła, oddając wrażenie grozy i przerażenia (il. 5). Czerwienie o odcieniach chłodnych podmalowano szarością - mieszaniną bieli i czerni. Nasteppnie na grissailowy modelunek położono czerwony laserunek, mieszaninę kraplaku i karminu lub sam karmin. Czerwienie o odcieniach cieplejszych podmalowano kolorem lokalnym, mieszaniną czerwieni organicznej, bieli ołowiowej i minii. Następnie położono laserunek karminem. Na uwagę zasługuje technika wykonania złotych promieni wokół postaci Michała Archanioła na tzw. „złotą farbe” podkładowa. Pozwalała ona na wykonanie złocenia na warstwie malarskiej i uzyskiwanie precyzyjnych ornamentów, linii czy napisów. W epitafium Gronau w składzie farby zidentyfikowano spoiwo olejne, minię, pigmenty żelazowe i niewielki dodatek kredy (il. 6). W szkole gdańskiej w okresie średniowiecza wykorzystywano już technikę nakładania złota na żółte podkłady, która była popularna w całej Europie ${ }^{9}$.

9 J. Olszewska-Świetlik, Technologia i technika gdańskiego malarstwa tablicowego drugiej połowy XV wieku, Toruń 2005, s. 279. 
Stwierdzono, o czym wspomniano już wcześniej, że warsztat, w którym wykonano epitafium Hansa Gronau, realizował zapewne więcej podobnych zamówień. Scena Sądu Ostatecznego została namalowana wcześniej. Fundator wybrał obraz i wtedy w dolnej części, w której zostawiono miejsce na domalowanie postaci, przedstawiono rodzinę Gronau. Zapewne w tym czasie dokonano również poprawek obrazu. Zmiany naniesiono w postaciach Chrystusa oraz Archanioła Michała. Dotyczą one kształtu fryzur oraz płaszcza Jezusa.

Technologia i technika malarska epitafium Gronau jest wpisana w tradycję malarstwa XVII-wiecznego. Obraz został namalowany z dobrą znajomością metod oraz z wykorzystaniem stosowanych w tym czasie materiałów. Z tradycją średniowieczną należy powiązać rodzaj drewnianego podobrazia. W tym czasie w Europie dominowały już podobrazia płócienne. W przypadku epitafium malarskiego, w którym ważną rolę odgrywały bogato rzeźbiona rama oraz tablice inskrypcyjne, bardziej naturalne było jednak zastosowanie podobrazia drewnianego.

Twórca epitafium Gronau wzorował się na nowatorskich wpływach malarstwa XVII-wiecznego, łączącego w sobie tradycję warsztatów północnych i innowacyjny styl szkoły włoskiej, która odchodziła od sztywno określonych norm, zastępując je bardziej wrażliwym widzeniem natury. Tradycja zasad cechowych warsztatów ustępowała indywidualnym poszukiwaniom artystycznym oraz poszukiwaniom innych środków wyrazu, eksperymentom technicznym.

$\mathrm{Na}$ etapie dotychczasowych badań technologicznych trudno wykazać, w jakim stopniu na warsztat malarski oddziaływał Anton Möller. Powiązania dotyczą przede wszystkim kompozycji oraz naśladowania sposobu modelowania malarskiego. Odpowiedź na postawione wyżej pytanie będzie możliwa po przeprowadzeniu wnikliwych analiz budowy technicznej obrazów Antona Möllera, który jest obiektem badań naukowców z historii sztuki, a którego warsztat malarski pozostał do tej pory nierozpoznaną tajemnica. 


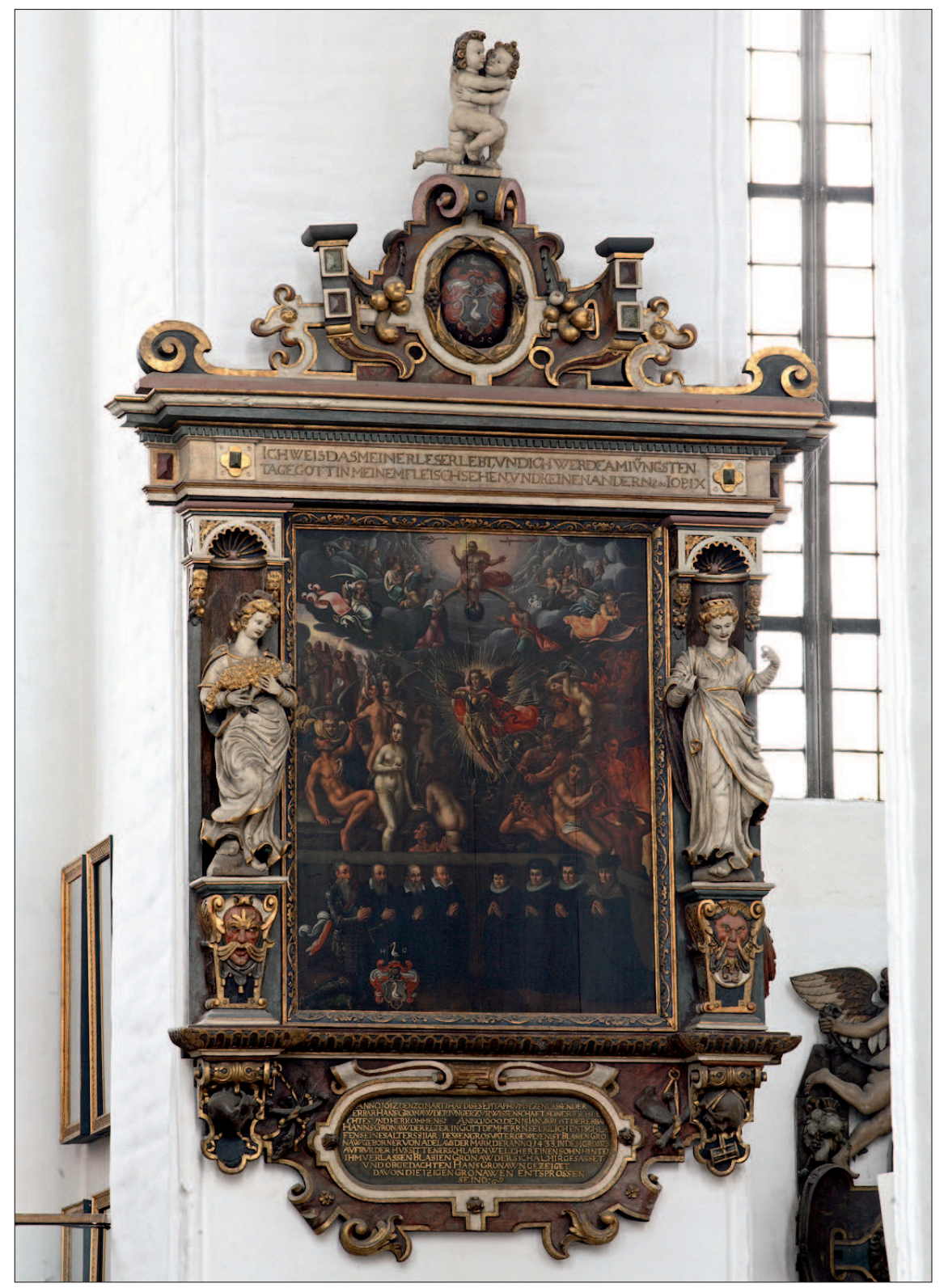

Il. 1. Epitafium Hansa Gronau, 1612 r., Bazylika Mariacka w Gdańsku. Rzeźbiona trzykondygnacyjna rama architektoniczna. Na dole tablica inskrypcyjna dotycząca genealogii rodziny. U góry sentencja religijna ozdobiona motywem rollwerkowo-okuciowym. W cześci centralnej obraz, po bokach dwie nisze z baldachimem, na podstawach maszkarony, na których ustawiono dwie rzeźby. Po lewej alegoria Cierpliwości z barankiem w ręku, po prawej Pobożności z Biblią. Górna część zwieńczona parą aniołków oraz kartuszem herbowym Hansa Gronau (fot. A. Skowroński) 


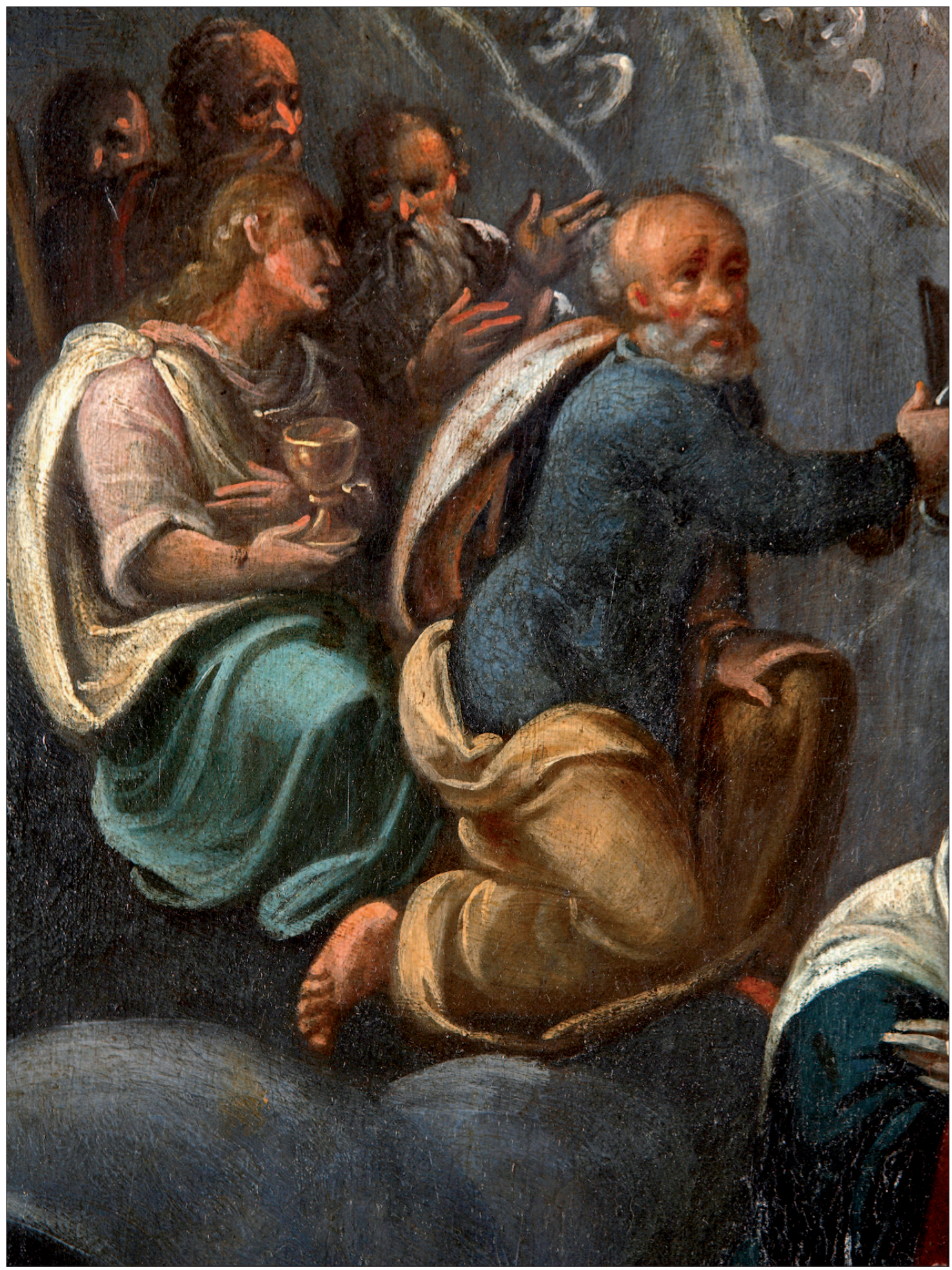

Il. 2. Epitafium Hansa Gronau, 1612 r., fragment. Sposób opracowania błękitnych szat z zastosowaniem azurytu naturalnego oraz nieba z zastosowaniem smalty (fot. A. Skowroński) 


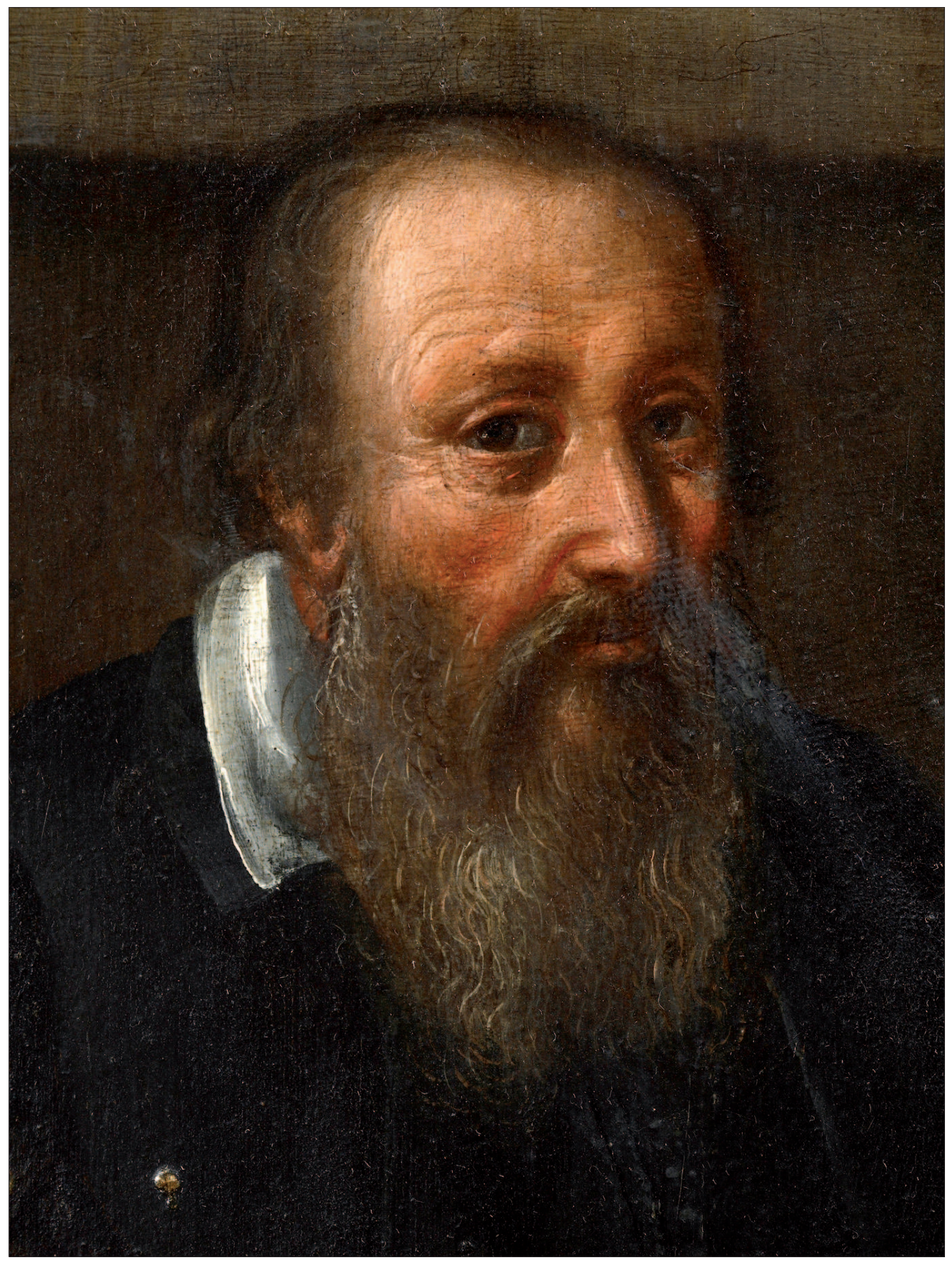

Il. 3. Epitafium Hansa Gronau, 1612 r., fragment. Sposób opracowania karnacji. Realistycznie namalowano portrety fundatorów (fot. A. Skowroński) 


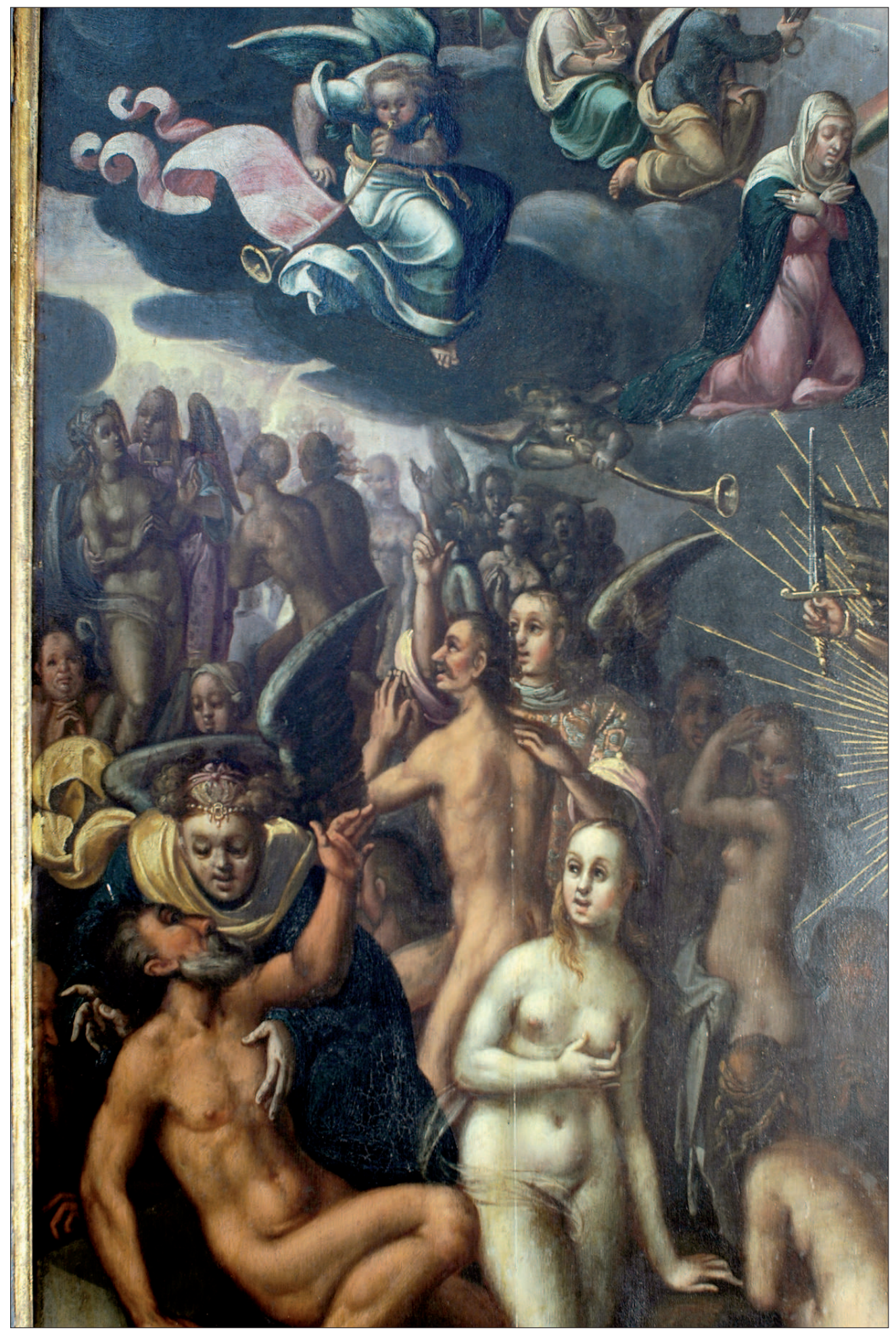

Il. 4. Epitafium Hansa Gronau, 1612 r. Sposób opracowania karnacji: cienie utrzymane w tonacji brązowej kontrastują z chłodnym różem w światłach (fot. R. Stasiuk) 


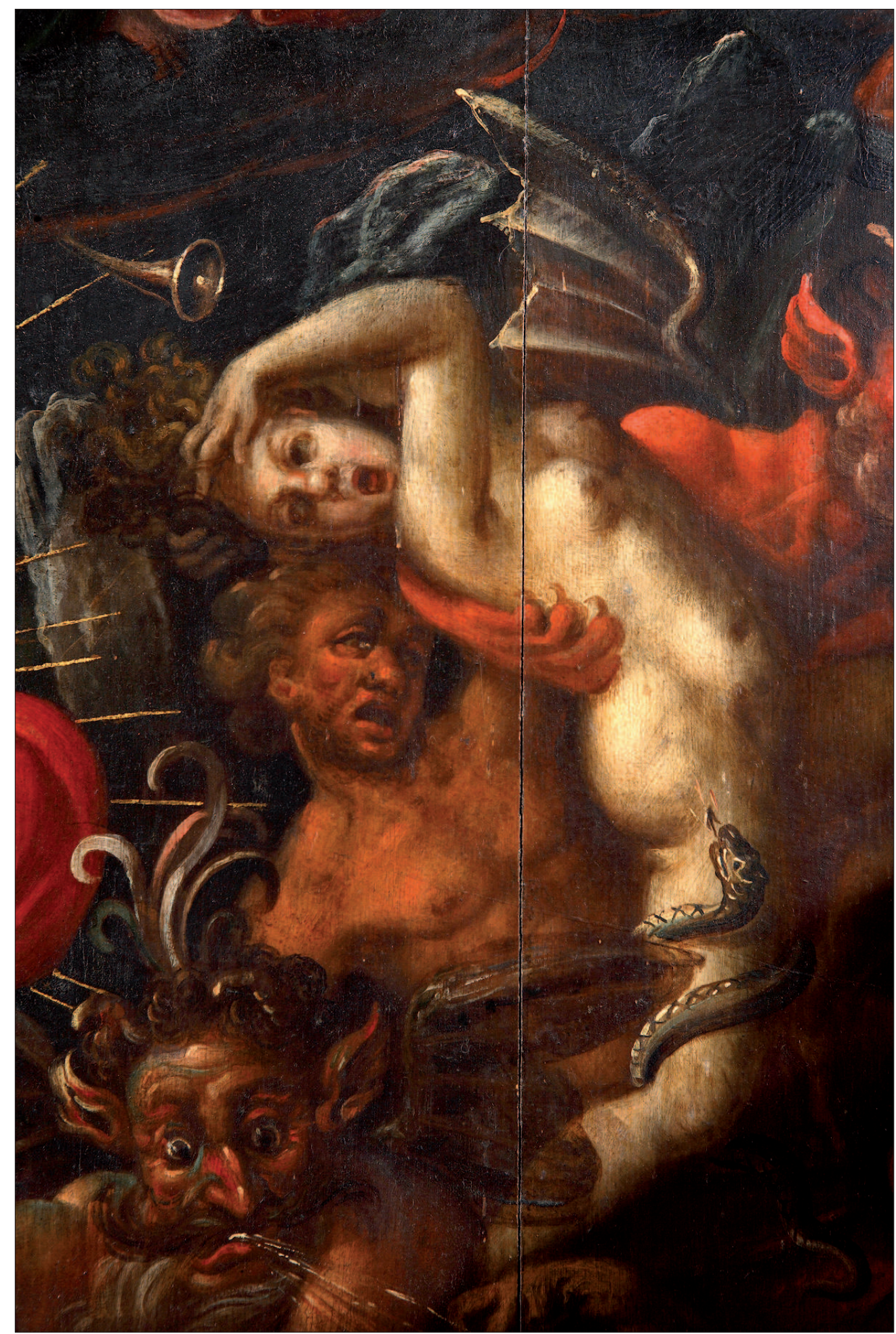

Il. 5. Epitafium Hansa Gronau, 1612 r., fragment. Ekspresyjny sposób przedstawienia piekła (fot. A. Skowroński) 


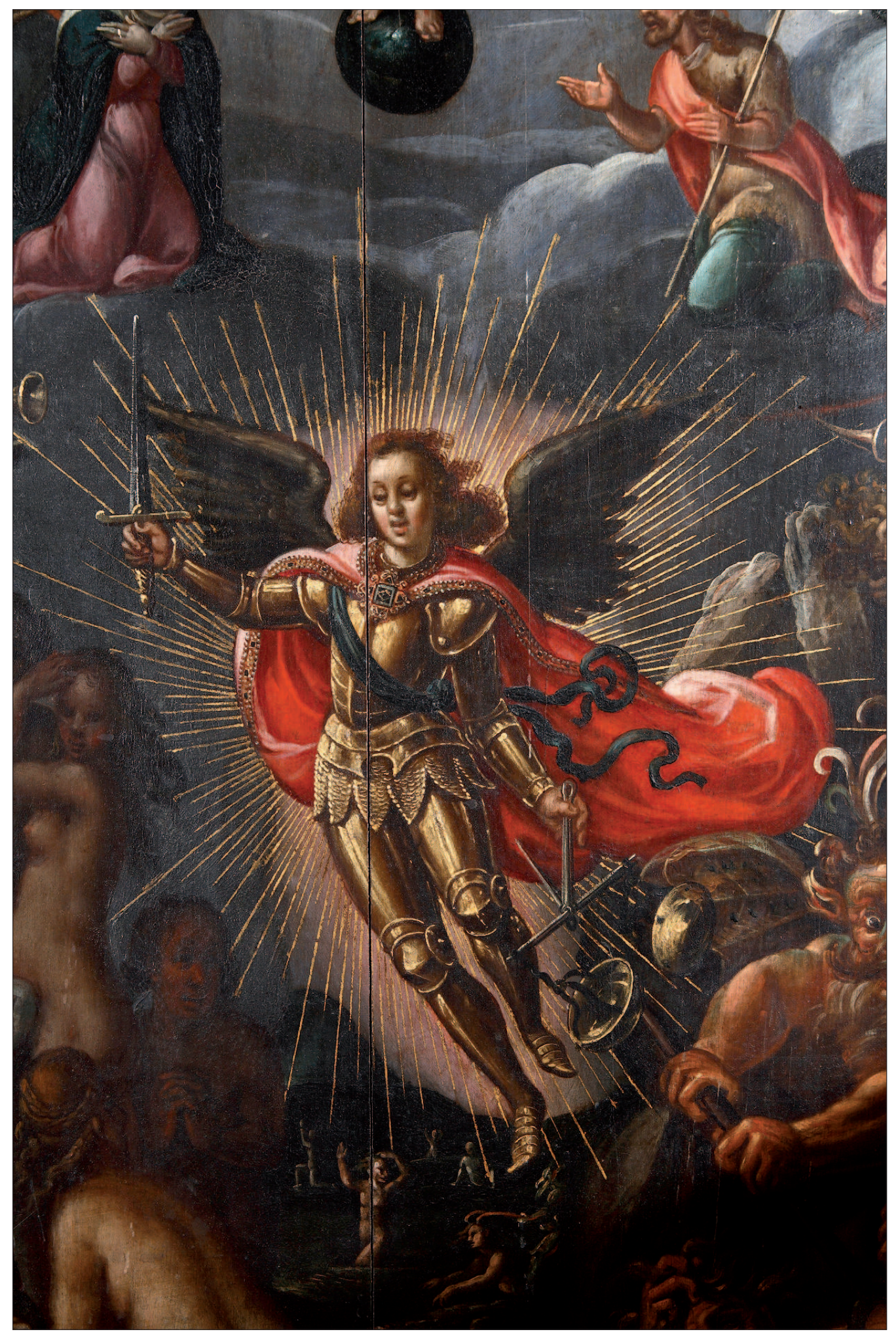

Il. 6a. Epitafium Hansa Gronau, 1612 r., fragment. Archanioł Michał, w tle złote promienie (fot. A. Skowroński) 

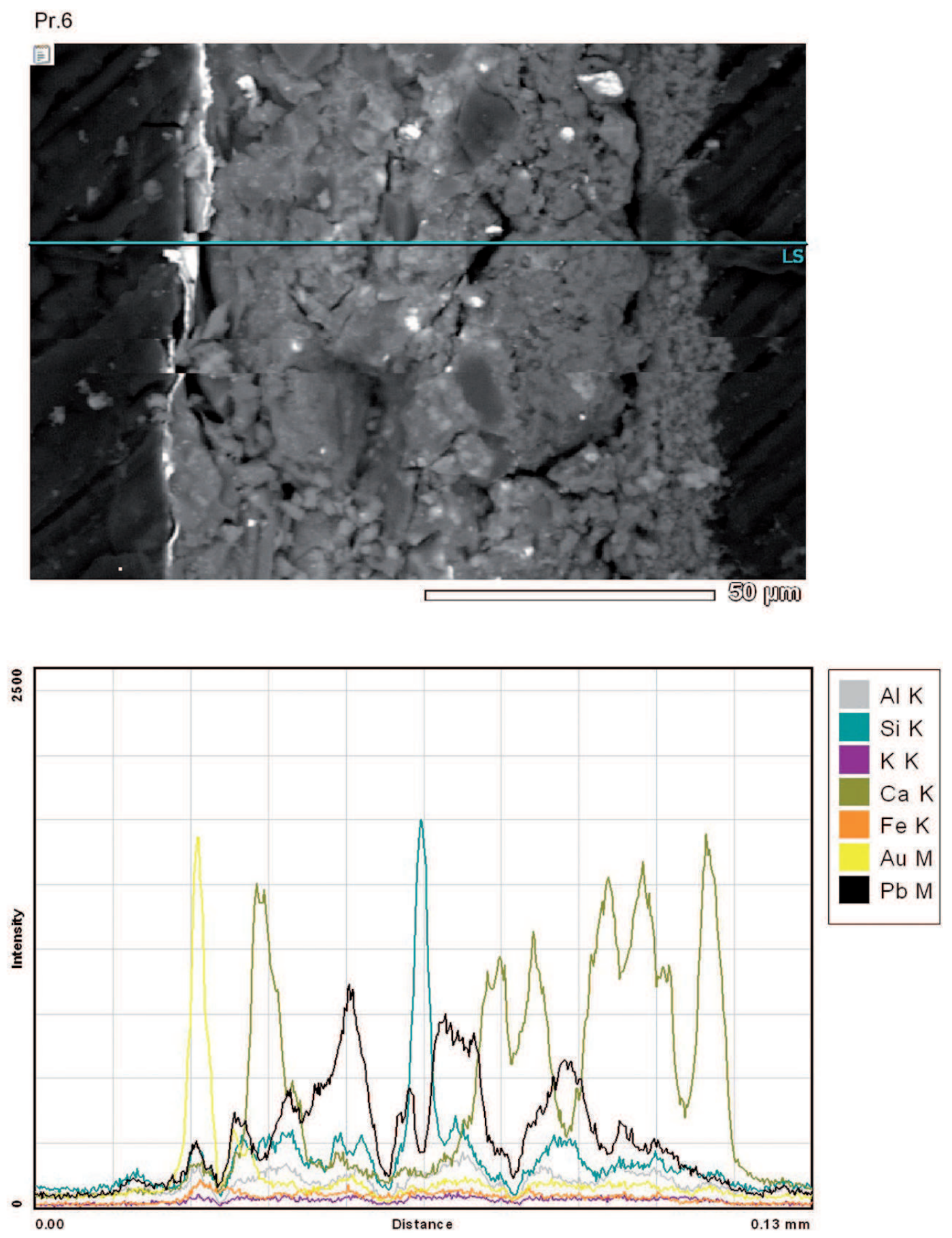

Il. 6b. Wyniki badań przekroju próbki z pozłoty. Zdjęcie skaningowe $\mathrm{w}$ świetle odbitym BEI. Wyniki energodyspersyjnej analizy z zastosowaniem mikrosondy elektronowej SEM-EDS po linii dla następujących pierwiastków: $\mathrm{Al}, \mathrm{Si}, \mathrm{K}, \mathrm{Ca}, \mathrm{Fe}, \mathrm{Au}, \mathrm{Pb}$ (wyk. M. Wróbel) 


\section{Summary}

\section{The issues of painters' workshop of the Hans Gronau epitaph painting from Our Lady's Basilica in Gdańsk}

The paper presents technical structure of the epitaph painting of Hans Gronau from Our Lady's Basilica in Gdańsk. The painting was executed in Gdańsk painter's workshop in the year 1612. Basing on the integrated physical, chemical and instrumental research artists' materials applied have been identified. In relation with historic and technological knowledge the most characteristic features of painters' workshop, that executed the painting have been characterised. Artists' technique and technology employed while executing the epitaph painting of Hans Gronau has been rooted in the tradition of $17^{\text {th }}$ century painting. The results of presented research contribute to the history of technology of painting of the Gdańsk school of the period from $17^{\text {th }}$ to $19^{\text {th }}$ century. 